\title{
MOTIVES AND PERCEIVED BENEFITS OF LEARNING TRANSLATION: A PRELIMINARY INVESTIGATION OF NON-NATIVE EFL STUDENT TEACHERS
}

\author{
MOTIVOS E BENEFÍCIOS CONSIDERADOS NA APRENDIZAGEM DE \\ TRADUÇÃO: UMA INVESTIGAÇÃO PRELIMINAR DE PROFESSORES NÃO \\ NATIVOS EM FORMAÇÃO DE EFL
}

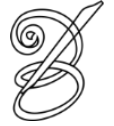 \\ Christy Fung-ming LIU* \\ The Education University of Hong Kong, Hong Kong
}

\begin{abstract}
The relationship between the teaching of English as a foreign language (EFL) and translation have been loosely entwined for a very long time. However, in the past decade, a number of academics have developed a renewed interest in the interplay between the two, and some teacher education universities offer translation courses to their student teachers. This paper presents findings from a preliminary study in which a questionnaire survey was used to identify the motives and perceived benefits of learning translation of 40 non-native EFL student teachers whose first language is Chinese, in a teacher education university in Hong Kong. The findings indicate that the pre-service teachers decided on taking translation courses or taking the subject as a minor because of their interest in both Chinese and English and their eagerness to improve their proficiency in these languages. The belief that learning translation might help non-native EFL student teachers secure a job in a language-related field is another prime motive for them to learn translation. It was discerned that they perceive learning translation to be beneficial to both their Chinese and English proficiency, especially in the knowledge of English grammar, and they have benefited in bilingual competence and career options. The paper concludes that although EFL student teachers tend not to work as professional translators after graduation, learning translation is deemed to have provided them with multifaceted benefits and increased their competitiveness in language-related fields.
\end{abstract}

Keywords: EFL teacher education. Student teachers. Learning motives. Language and translation.

Resumo: A relação entre o ensino de Inglês como Língua Estrangeira (EFL) e a tradução está entrelaçada há muito tempo. Contudo, na última década, diversos acadêmicos têm desenvolvido um interesse renovado em sua interação e algumas universidades de formação de professores oferecem cursos de tradução para os seus professores em formação. Esse trabalho apresenta os resultados de um estudo preliminar no qual um questionário foi utilizado para identificar os motivos e benefícios considerados na aprendizagem de tradução por 40 professores não nativos de EFL cuja primeira língua é o chinês, em uma universidade de formação de professores em Hong Kong. Os resultados indicam que os professores em formação decidiram fazer cursos de tradução ou estudar a disciplina como segunda habilitação devido ao seu interesse no chinês e no inglês e à sua vontade de melhorar a proficiência nestas línguas. A crença de que aprender Tradução pode ajudar aos estudantes não nativos de EFL a conseguir um emprego em um campo relacionado ao idioma é outro motivo principal para eles aprenderem a traduzir. Notou-se que eles percebem o aprendizado da Tradução como benéfico tanto para sua proficiência em chinês quanto em inglês, especialmente no conhecimento da gramática inglesa, e que eles se beneficiaram com a competência bilíngue e opções de carreira. $\mathrm{O}$ artigo conclui que, embora os professores em formação de EFL não trabalhem como tradutores profissionais após a graduação, considera-se que a aprendizagem de Tradução lhes proporcionou benefícios multifacetados e aumentou a sua competitividade em áreas relacionadas com a língua.

Palavras-chaves: Formação de professores EFL. Professores em formação. Motivos de aprendizagem. Língua e Tradução.

RECEIVED ON: August $25^{\text {th }}, 2019$

ACCEPTED ON: November $28^{\text {th }}, 2019$

PUBLISHED IN: January 2020

LIU, Christy. Motives and perceived benefits of learning translation: A preliminary investigation of non-native EFL student teachers. Belas Infiéis, Brasília, v. 9, n. 1, p. 73-87, 2020. 


\section{Introduction}

here was once a close relationship between language teaching and translation. Before
the gradual shift towards the Communicative Language Teaching approach, the
grammar-translation method was prevalent among EFL teachers in the Chinese context (Yu 2001). For example, Cheng and Wang (2004) surveyed a group of 47 in-service EFL secondary teachers in China in 2002. They found that $74.5 \%$ of the teachers received education through the grammar-translation method when they were taught English. Although the two fields lost contact with each other for a long time, a number of academics have developed a renewed interest in the interplay between the two in the past decade. For instance, Pym (2017) revisits the relationship between them, noting that the role of translation in language teaching has not been examined in a comprehensive manner. Cook (2010) recognizes the lack of research in this particular area and repudiates the claim that translation should be prohibited in the EFL classroom. As he says:

Translation is a real-world activity outside the classroom. It is outcome-oriented: a successful translation is one that works. It promotes a focus on form as an offshoot of a communicative need, rather than as an end itself [...] Translation [...] enables the apparently disparate focuses on communication and form to be reintegrated. (Cook 2010: 30-31)

Cook suggests re-establishing translation as a part of language teaching. Tsagari and Floros (2013) co-edited a book to examine whether Cook's call for reinstating translation as a component of language teaching and assessment has borne fruit and in what ways. The two authors conclude that 'the communicative turn in Language Teaching, contrary to the excluding tendencies of the past, has now created a welcoming context for translation' (Tsagari and Floros 2013: xi). According to these scholars, the missing link between the two fields is worth further revisiting.

Coincidentally, a teacher education university in Hong Kong, which has a particular focus on the English language, Chinese language, creative arts, liberal arts, social sciences and early childhood education, has launched three translation courses as free electives for all undergraduates. These translation courses are 'Introduction to Translation', 'Contrastive Analysis of Languages and Translation' and 'Practical Translation'. They aim to develop students' Chinese and English translation skills, strengthen their Chinese and English language proficiency, enhance students' cultural awareness and train them to become bilingual communicators. They also aim to broaden students' interdisciplinary horizons and their career 
options. In short, the courses are designed to benefit students in their language proficiency, cultural awareness and future career. Students completing these three translation courses and two other language-related courses can claim a minor in Translation, which was launched by the university in 2017.

It was observed that the translation courses attracted non-native EFL student teachers whose first language is Chinese. For example, when 'Introduction to Translation' was first offered, over $75 \%$ of the students enrolling in the course were non-native EFL student teachers. Typically, student teachers tend to take electives or a minor in disciplines that either allow them to teach one more subject, such as music, at a local school (Ho and Law 2002) or equip them with skills for teaching students with special educational needs, i.e. special education (Pugach, Blanton and Correa 2011). Thus, it is quite unconventional for non-native EFL pre-service teachers to opt to take translation as their elective or minor. Because of this phenomenon, it has come to the author's attention that some relationship between EFL teacher training and translation in higher education may exist. In particular, it is worth knowing non-native EFL student teachers' motives for learning translation and whether or not they benefit from studying the subject. And, if learning translation is found to be beneficial to them, it is also worth examining what the actual benefits are. For example, do student teachers perceive that their language proficiency has been enhanced, their cultural awareness and their career options have been broadened after taking the courses? Unfortunately, there is little literature about non-native EFL pre-service teachers learning translation in a university setting. Some scholars express the need for offering translation courses to non-translation majors (Lung 2005). However, little has been studied on translation learning among non-translation majors, not to mention among nonnative EFL student teachers taking translation courses. Although Tsai and Tsai (2012) found that foreign language majors study translation to improve their English proficiency, the study did not include pre-service teachers.

In Hong Kong, a number of scholars in the field of English language teaching advocate that L1 can serve to scaffold English language learning although the city's English language teachers are urged to use English "in all English lessons and beyond: teachers should teach English through English and encourage learners to interact with one another in English" (Curriculum Development Council 2004: 109). For example, Swain, Kirkpatrick and Cummins (2011) stressed that EFL teachers can provide students with translations for learning difficult grammar and vocabulary. They explained that "providing translations to clarify the meaning of words, phrases and grammatical structures is efficient" (Swain et al. 2011: 10). They added that 
using translation to compare and contrast the syntactic differences between Chinese and English can help students to learn and increase their interest in language learning. Given this, obtaining some translation knowledge and skills would be useful for non-native EFL pre-service teachers, as they may use such skills in teaching English in the Hong Kong context. It is believed that the results of the present study will benefit both the fields of Translation Studies and English Language Studies.

\section{Research questions and methodology}

The objectives of the present paper are to carry out a preliminary investigation into nonnative EFL student teachers' motives for learning translation and their perceived benefits of studying translation. These two objectives lead to the following research questions:

1. What are non-native EFL student teachers' motives for learning translation?

2. What are the perceived benefits for non-native EFL student teachers to learn translation? To be precise, how can translation courses benefit their Chinese proficiency, English proficiency, bilingual competence, translation skills, cultural awareness and career path (these are also the intended learning outcomes of the translation courses)?

These objectives and research questions are important for several reasons. First of all, they amass relevant data about the voices of non-native EFL pre-service teachers themselves, adhering to the notion of learner-centered teaching. According to Astin (1999), the design of the program structures and curricula in higher education including teacher training tends to revolve around the blend of both the subject-matter theory and the individualized theory. This means that a certain number of compulsory courses regarded as possessing true worth are assigned to tertiary students, but students enjoy the autonomy to enrol in preferred elective courses, with the purpose of transmitting the specialized knowledge in academia to students, as well as catering for the diversity of needs of every individual. To be more specific, the provision of the component of free electives in university curricula intends to promote flexibility so that students realize their aspirations, interlink an assortment of academic disciplines (Movchan and Zarishniak 2017), and respond to students' intrinsic motivations for learning, i.e. the decisive factor of how they opt for elective courses (Hedges, Pacheco and Webber 2014). Students can take electives that are similar to or markedly different from what they major in, as long as they 
have interest in taking them, while the perceived amount of learning value derived from the courses is also taken into account (Babad and Tayeb 2003). As a result, the feedback gathered from non-native EFL pre-service teachers can serve as invaluable resources for both EFL teacher education and translator education. Research results can also assist educators in developing curricula which meet learners' needs (Li 2000). Furthermore, Creese and Blackledge (2010) contend that bilingual instructional strategies, including the use of translation, should be adopted when teaching EFL, since they can help bilingual students establish the connection between their first language (L1) and English in their daily lives. Therefore, the research results will provide insights into how to assist bilingual teachers to make judicious use of translation in teaching English in a classroom where both the teacher and the students share the same L1. Cook (2010: 156) calls for 'new elements [being] introduced into teacher education'. Thus, the present study takes the lead in exploring the interrelationship between EFL teacher education and translation learning, i.e. how learning translation can benefit EFL student teachers themselves.

This study was conducted with a group of students receiving English language teacher education in a Hong Kong teacher education university. They have taken at least one translation course or were taking a translation course at the university from January to March 2018. The study started in January 2018 and ended in March 2018, during which a stratification method was used by inviting non-native EFL student teachers to fill in a questionnaire. A total of 40 complete and valid questionnaires were returned. The first part of the questionnaire asked the respondents to give their background information, career preference and proficiency in Chinese and English. This part also asked them to give their reason(s) for choosing to take translation courses. The following three parts invited respondents to indicate to what extent they agreed with statements concerning the benefits of studying translation pertaining to language, culture and career. The response categories were scored as follows: $1=$ strongly disagree; $2=$ disagree; 3 = neutral; 4 = agree; 5 = strongly agree.

\section{Results}

Of the 40 respondents, $35(87.5 \%)$ are female and $5(12.5 \%)$ are male. The respondents, all undergraduates, are young adults, with a mean age of $20.87 ; 24(60 \%)$ of them are $21-25$ years, and $15(37.5 \%)$ are 18-20. One respondent (2.5\%) did not answer the question. Thirtyfour $(85 \%)$ are from Hong Kong, and $6(15 \%)$ are from mainland China. Since the translation courses are open to all undergraduates, students from different cohorts can enrol in the course. 
Of these 40 student teachers, 2 (5\%) are year one students, 9 (22.5\%) are year two students, 11 $(27.5 \%)$ are year three students, $12(30 \%)$ are year four students, and $6(15 \%)$ are year five students who are soon-to-be graduates. The mean years of study is 3.28, showing that most of them are deemed to be fairly familiar with university education and teacher education. When asked to indicate their Chinese proficiency, the mean value is 3.83 , on a scale of 1 to 5 , where $1=$ poor and $5=$ excellent. For their English proficiency, the mean is 3.65. The result suggests that the participants, all English majors and prospective teachers of English, perceive themselves to be slightly more proficient in Chinese, which is the first language of the respondents. The questionnaire also attempted to gather information about whether or not the respondents are taking Translation as a minor (i.e. three translation courses plus two languagerelated courses). A total of 30 respondents (75\%) indicated 'yes', 9 (22.5\%) indicated 'no' and one did not answer (2.5\%). This result reveals that the majority of the respondents would like to study the discipline in more depth. In addition, the respondents were asked to indicate the likelihood of their becoming a schoolteacher or a translator after graduation, on a scale of 1 to $5(1=$ very unlikely and $5=$ very likely $)$. Of these 40 respondents, the mean value of the

78 likelihood of being a schoolteacher is 3.43. That of the likelihood of being a translator is 2.98 . The results are in line with social expectations that student teachers of English language, in general, will become English teachers working in a school setting.

\section{Non-native EFL students' motives for learning translation}

The first objective of the present study is to discover the reasons why non-native EFL student teachers chose to take translation courses. Although these student teachers major in English language education, it was found that bilingual competence plays a crucial role in their motives for learning translation. Table 1 shows that the majority of the respondents $(n=29$; $72.5 \%$ ) said that they took translation courses because they were interested in both Chinese and English languages. A total of 25 respondents (62.5\%) made it clear that they wanted to improve both their Chinese and English. Only 8 (20\%) and 5 (12.5\%) showed that they were interested in English and wanted to improve their English respectively. Similarly, only 6 (15\%) indicated that they were interested in Chinese and 6 (15\%) said that they wanted to improve their Chinese. These data imply that a certain number of non-native EFL student teachers decided on studying translation in pursuit of greater bilingual competence rather than greater proficiency in one particular language. 
Table 1 - Reasons for choosing to take translation courses

\begin{tabular}{|l|c|c|}
\hline \multicolumn{1}{|c|}{ Reason } & $\begin{array}{c}\text { Number of } \\
\text { respondents } \\
\text { (n) }\end{array}$ & $\begin{array}{c}\text { Percentage } \\
(\%)\end{array}$ \\
\hline I am interested in the English and Chinese languages. & 29 & 72.5 \\
\hline I want to find a job in a language-related field. & 29 & 72.5 \\
\hline I want to improve my English and Chinese languages. & 25 & 62.5 \\
\hline I want to improve my knowledge and skills in teaching languages. & 22 & 55 \\
\hline I want to become a translator/an interpreter. & 16 & 40 \\
\hline I am interested in English. & 8 & 20 \\
\hline I am interested in Chinese. & 6 & 15 \\
\hline I want to improve my Chinese. & 6 & 15 \\
\hline I want to improve my English. & 5 & 12.5 \\
\hline
\end{tabular}

Elaborated by: Christy Fung-ming Liu

The belief that learning translation might help non-native EFL student teachers secure a job in a language-related field is another prime motive for them to learn translation. A total of 16 respondents (40\%) indicated that they would like to pursue the career of translator/interpreter, and $29(72.5 \%)$ expressed their wish to find a job in a language-related field. This means that learning translation might allow them to be more capable and competitive in language competence, and hence they can have better credentials when applying for a job that requires considerable language proficiency. One job in a language-related field in Hong Kong is the Official Languages Officer in the government. The post, which is a dream job of language graduates in the city, is responsible for translating, interpreting and producing documents written in both Chinese and English, the official languages of Hong Kong.

Over half the respondents $(n=22,55 \%)$ said that they were motivated to learn translation to improve their knowledge and skills in teaching languages. Since many of them are about to have their school placement $(n=27,67.5 \%)$, the author will conduct a follow-up study with these student teachers to examine whether and how they apply the knowledge acquired in translation lessons in teaching English during their teaching practicum. It is hoped that the results can offer some practical insights into future possibilities for using translation in language teaching.

The above findings furnish us with a better grasp of the motives for non-native EFL student teachers to learn translation: their interest in both Chinese and English and their intent to enhance their proficiency in these languages. Also, some of them believe that the knowledge and skills gained from the discipline can improve their competitiveness in the job market as well as improve their teaching skills. 
The questionnaire for the present study encompasses three parts to examine the benefits of studying translation: (1) language-related benefits, (2) culture-related benefits and (3) careerrelated benefits. The respondents were asked to indicate the extent to which they agree or disagree with the statements concerning the benefits of studying translation related to the three parts, on a scale of 1 to five ( $1=$ strongly disagree and $5=$ strongly agree). Research findings on these three parts are scrutinized with the purpose of answering the second research question.

\section{Language-related benefits}

The language-related benefits are further divided into four aspects: (1) Chinese-related benefits, (2) English-related benefits, (3) benefits related to bilingual competence and (4) benefits related to translation skills.

\subsection{Chinese-related and English-related benefits}

The results show that the respondents perceive learning translation to be beneficial to both their Chinese (L1) and English (L2) proficiency although, in comparison with the results between Chinese-related and English-related benefits, the latter demonstrates a slightly higher mean value. Table 2 shows that the respondents tend to agree that learning translation can increase their overall Chinese proficiency (mean value $=4.00$ ) and their overall English proficiency (mean value $=4.15$ ). In a similar way, they tend to agree that their English reading skills are improved (mean value $=4.13$ ). Except for writing skills, all the results of Englishrelated benefits have a higher mean value than that of Chinese-related benefits. In particular, the result of the extension of their English grammar knowledge is noteworthy because the mean value is the highest of all the Chinese-related and English-related benefits (mean=4.23). This result also implies that most of the non-native EFL students taking part in this study perceive that translation can be a means to enhance their English (their L2) grammar. In translation classes, when students are required to translate a text into another language, their grammatical accuracy is assessed. If necessary and worthwhile, grammar teaching is also explicitly incorporated in lectures. $\mathrm{Li}$ (2001) acknowledges the importance of the inclusion of grammar teaching in teaching translation, saying that 'teaching translation students some grammar can be of great help with the reproduction, revision and editing of translated texts, thus effectively reducing the errors in their translations' (349). The data of the present study suggest that student teachers of the English language perceive learning translation to benefit them in the knowledge and mastery of English grammar. This may also enhance their quality of teaching because, as 
Choi and Lee (2016) emphasize, there exists a positive correlation between English proficiency and teaching abilities.

Table 2 - Results of Chinese-related and English-related benefits perceived by non-native EFL student teachers taking translation courses

\begin{tabular}{|c|c|c|c|c|c|}
\hline \multicolumn{3}{|c|}{ Chinese-related benefits } & \multicolumn{3}{|c|}{ English-related benefits } \\
\hline Studying translation helps me... & Mean & SD & $\begin{array}{l}\text { Studying translation helps } \\
\text { me... }\end{array}$ & Mean & SD \\
\hline $\begin{array}{l}\text { Increase my overall Chinese } \\
\text { proficiency. }\end{array}$ & 4.00 & 0.51 & $\begin{array}{l}\text { Increase my overall English } \\
\text { proficiency. }\end{array}$ & 4.15 & 0.53 \\
\hline $\begin{array}{l}\text { Increase my reading skills in } \\
\text { Chinese. }\end{array}$ & 3.88 & 0.65 & $\begin{array}{l}\text { Increase my reading skills in } \\
\text { English. }\end{array}$ & 4.13 & 0.65 \\
\hline $\begin{array}{l}\text { Increase my writing skills in } \\
\text { Chinese. }\end{array}$ & 4.10 & 0.59 & $\begin{array}{l}\text { Increase my writing skills in } \\
\text { English. }\end{array}$ & 4.08 & 0.53 \\
\hline $\begin{array}{l}\text { Extend my knowledge of Chinese } \\
\text { grammar. }\end{array}$ & 3.98 & 0.73 & $\begin{array}{l}\text { Extend my knowledge of } \\
\text { English grammar. }\end{array}$ & 4.23 & 0.58 \\
\hline $\begin{array}{l}\text { Avoid producing Europeanized } \\
\text { Chinese. }\end{array}$ & 3.95 & 0.68 & $\begin{array}{l}\text { Avoid producing 'Hong Kong } \\
\text { English'/ 'Chinglish'. }\end{array}$ & 4.03 & 0.53 \\
\hline $\begin{array}{l}\text { Understand how texts are organized } \\
\text { in Chinese. }\end{array}$ & 4.03 & 0.58 & $\begin{array}{l}\text { Understand how texts are } \\
\text { organized in English. }\end{array}$ & 4.13 & 0.46 \\
\hline
\end{tabular}

Elaborated by: Christy Fung-ming Liu

\subsection{Benefits related to bilingual competence}

Hopkins (2013) has noticed the trend that teachers who are professionally qualified as bilingual are able to teach students effectively by incorporating students' first language, prior knowledge and life experiences into teaching, which helps create a better learning experience for bilingual students. According to the results shown in Table 3, learning translation, from the respondents' perspective, offers benefits to their bilingual competence; the mean value of the extent to which studying translation develops students' overall bilingual competence is 4.28. The non-native EFL student teachers recognize that learning translation allows them to understand the similarities and differences between their L1 (Chinese) and L2 (English), with mean values of 4.00 and 4.10 respectively. They also tend to agree that translation lets them appreciate the two languages in a systematic way and from a linguistic approach (mean $=4.08)$. 
Table 3 - Results of benefits related to bilingual competence perceived by non-native EFL teachers taking translation courses

\begin{tabular}{lcc}
\hline \multicolumn{1}{c}{ Studying translation helps me... } & Mean & SD \\
\hline $\begin{array}{l}\text { Develop my overall bilingual competence. } \\
\text { Understand the similarities between the two languages. }\end{array}$ & 4.28 & 0.55 \\
\hline Understand the differences between the two languages. & 4.00 & 0.64 \\
\hline $\begin{array}{l}\text { Strengthen my ability to appreciate the two languages in a systematic way } \\
\text { and from a linguistic approach. }\end{array}$ & 4.08 & 0.67 \\
\hline Elaborated by: Christy Fung-ming Liu & & 0.57 \\
\hline
\end{tabular}

\subsection{Benefits related to translation skills}

The respondents generally acknowledge the benefit that learning translation fosters the development of their skills in both practical and literary translation. Table 4 shows that they tend to agree that their translation skills have been sharpened in general during the process of learning translation (mean value $=4.10$ ), and, more precisely, they have acquired better skills in practical translation (mean value $=4.00$ ) and literary translation (mean value $=4.03$ ). These

82 data suggest that learning translation benefits non-native EFL student teachers' development of translation skills, and there is a balance between their capabilities to translate texts in specialized fields and literary texts. Lung and Yan (2004) assert that both the teaching and learning of literary translation and practical translation are essential to translation students since the former offers subtle but real impact on students' knowledge of culture and use of grammar and vocabulary while the latter meets the market's needs. Nonetheless, in the item about whether they are capable of undertaking translation tasks in real-life situations, the mean is slightly lower, 3.78; on top of that, the mean value of their awareness to acquire ethical values when doing translation is 3.80 , which is lower than the mean values for the previous items. Because the respondents are still undergraduates, they may lack opportunities to practice their skills and to experience ethical dilemmas in translating texts. 
Table 4 - Results of benefits related to translation skills perceived by non-native EFL teachers taking translation courses

\begin{tabular}{lcc}
\hline \multicolumn{1}{c}{ Studying translation helps me... } & Mean & SD \\
\hline Sharpen my translation skills in general. & 4.10 & 0.50 \\
\hline $\begin{array}{l}\text { Sharpen my skills in practical translation such as translating official and } \\
\text { clerical documents. }\end{array}$ & 4.00 & 0.72 \\
\hline Sharpen my skills in literary translation. & 4.03 & 0.70 \\
\hline Strengthen my awareness to acquire ethical values when doing translation. & 3.80 & 0.72 \\
\hline Develop my ability to deal with authentic translation tasks outside campus. & 3.78 & 0.70 \\
\hline Elaborated by: Christy Fung-ming Liu & &
\end{tabular}

In summary, the above results suggest that most of the non-native EFL student teachers perceive that translation courses brought them language-related benefits. In particular, they agree that their English proficiency and bilingual competence were enhanced, because the mean values of the items related to these two aspects are 4.0 or above. In what follows, the ways the respondents perceive the benefits related to culture and career after taking translation courses will be analysed.

\section{Culture-related benefits}

In comparison with the results about language-related benefits, the results of culturerelated benefits show lower mean values in general. Yet it is believed that learning translation benefits the non-native EFL student teachers' cultural awareness to a certain extent. They reported a mean value of 3.78 when asked whether their general cultural awareness was enhanced after taking translation courses. From a micro perspective, their knowledge of Western culture, their understanding of the similarities between Chinese and Western cultures as well as their respect for others' culture are heightened to some extent, as the mean values of these three items are all 3.88. Table 5 shows that the highest mean value (3.95) was found in the respondents' understanding of the differences between Chinese and Western cultures. Nault (2006) proposes that ELT educators are obliged to keep abreast of a variety of cultures in the world and include the teaching of culture when tailoring appropriate materials for teaching EFL, so that their students' awareness of culture can be enriched in the globalized world. It is therefore suggested that non-native EFL student teachers enhance their cultural awareness for their future teaching. Learning translation can be one of the methods of enhancing EFL pre- 
service teachers' cultural awareness, because people need to take cultural issues into consideration when rendering a text into another language.

Table 5 - Results of culture-related benefits perceived by non-native EFL teachers taking translation courses

\begin{tabular}{lcc}
\hline \multicolumn{1}{c}{ Studying translation helps me... } & Mean & SD \\
\hline $\begin{array}{l}\text { Deepen my understanding of the differences between Chinese and } \\
\text { Western cultures. }\end{array}$ & 3.95 & 0.68 \\
\hline $\begin{array}{l}\text { Deepen my understanding of the similarities between Chinese and } \\
\text { Western cultures. }\end{array}$ & 3.88 & 0.61 \\
\hline Advance my understanding of Western culture. & 3.88 & 0.65 \\
\hline Respect and embrace others' culture. & 3.88 & 0.61 \\
\hline Enhance my cultural awareness in general. & 3.78 & 0.58 \\
\hline Advance my understanding of Chinese culture. & 3.75 & 0.67 \\
\hline
\end{tabular}

Elaborated by: Christy Fung-ming Liu

\section{Career-related benefits}

The results suggest that the respondents have received benefits for their careers from taking translation courses. When they were asked whether or not studying translation helps broaden their career options, a high mean value of 4.33 was reported. In addition, the respondents tend to agree that studying translation increases their competitiveness in the job market (mean=4.13). Such results imply that taking translation courses allowed them to enjoy the advantages brought by occupational mobility. Sinclair (2008) reviewed the literature about the motives for entering the teaching sector and identifies the limited number of job options as one of them. However, it is not easy to get a permanent teaching job in Hong Kong. Law (2018) points out that job uncertainty gnaws at the city's contract teachers in public schools and causes low morale. In particular, beginning teachers in Hong Kong are faced with the challenge of 'increasing insecurity and uncertainty' in the job market (Tang 2011: 366). In the current sample, $72.5 \%$ of the respondents decided to learn translation because they wanted to seek employment in a language-related field. Learning translation, thus, may help non-native EFL student teachers assert themselves and become less worried about their future. 
Table 6 - Results of career-related benefits perceived by non-native EFL teachers taking translation courses

\begin{tabular}{lcc}
\hline \multicolumn{1}{c}{ Studying translation helps me... } & Mean & SD \\
\hline Broaden my career options. & 4.33 & 0.66 \\
\hline Increase my competitiveness in the job market. & 4.13 & 0.52 \\
\hline
\end{tabular}

Elaborated by: Christy Fung-ming Liu

\section{Conclusion}

This research study was conducted because of the author's observation that a group of non-native EFL student teachers have taken/been taking translation as their free elective or even as their minor since the launch of the subject in a teacher education university in Hong Kong. This phenomenon gave me the perception that learning translation may benefit these student teachers. The objectives of the present study are to identify non-native EFL student teachers' motives for learning translation and to discern their perceived benefits. Findings suggest that pre-service teachers chose to learn translation because they were interested in both Chinese and English and they would like to improve their mastery of these languages. They perceive learning translation to be beneficial to both their overall Chinese and English proficiency, especially in the knowledge of English grammar. They also consider studying translation to be beneficial in bilingual competence and career paths. It should be noted that their translation skills and cultural awareness have benefited to a lesser degree.

The data were collected from 40 non-native EFL student teachers in Hong Kong. Although the sample size is sufficient for statistical analysis, it may limit the generalizability of the findings. Also, the present quantitative approach is not yet complemented by qualitative interviews. However, the findings furnish us with a clearer picture about the link between translation and EFL teacher education. Future research projects with a focus on how the knowledge and skills of translation can facilitate EFL teaching are worthwhile. It is also worth further investigating whether EFL student teachers are able to capitalize on the knowledge and skills acquired from learning translation and to bring translation to the EFL classroom, as advocated by Cook (2010).

\section{REFERENCES}

Astin, A. W. "Student Involvement: A Developmental Theory for Higher Education." Journal of College Student Development, vol. 40, no. 5, 1999, pp. 518-529.

Babad, E., and A. Tayeb. "Experimental Analysis of Students' Course Selection." British Journal of Educational Psychology, vol. 73, no. 3, 2003, pp. 373-393. 
Cheng, L., and H. Wang. "Understanding Professional Challenges Faced by Chinese Teachers of English.” TESL-EJ 7, vol. 4, 2004, pp. 16-31.

Choi, E., and J. Lee. "Investigating the Relationship of Target Language Proficiency and Selfefficacy among Non-native EFL Teachers." System, vol. 58, 2016, pp. 49-63.

Cook, G. Translation in Language Teaching: An Argument for Reassessment. Oxford: Oxford University Press, 2010.

Creese, A, and A. Blackledge. "Translanguaging in the Bilingual Classroom: A Pedagogy for Learning and Teaching?" The Modern Language Journal, vol. 91, no. 1, 2010, pp. 103115 .

Curriculum Development Council. English Language Education Key Learning Area: English Language Curriculum Guide (Primary 1-6). Hong Kong: Education and Manpower Bureau, 2004.

Hedges, M. R., G. A. Pacheco, and D. J. Webber. "What Determines Students' Choices of Elective Modules?" International Review of Economics Education, vol. 17, 2014, pp. $39-54$.

Ho, W. C., and W. W. Law. 2002. "Music Education in Taiwan: The Dynamics and Dilemmas of Globalization, Localization and Sinophilia." Curriculum Journal, vol. 13, no. 3, 2014, pp. 339-360.

Hopkins, M. "Building on Our Teaching Assets: The Unique Pedagogical Contributions of Bilingual Educators.” Bilingual Research Journal, vol. 36, no. 3, 2013, pp. 350-370.

Law, Z. "Job Uncertainty Gnaws at Hong Kong's Contract Teachers in Public Schools and Causes Low Morale.” South China Morning Post, July 13, 2018.

Li, D.F. "Needs Assessment in Translation Teaching: Making Translator Training More Responsive to Social Needs." Babel, vol. 46, no. 4, 2000, pp. 289-299.

---. “Language Teaching in Translator Training.” Babel, vol. 47, no. 4, 2001, pp. 343-354.

Lung, R. “Translation Training Needs for Adult Learners.” Babel, vol. 51, no. 3, 2005, pp. 224237.

Lung, R., and J. Yan. "Attitudes Towards a Literature-oriented Translation Curriculum." Babel, vol. 50, no. 1, 2004, pp. 3-12.

Movchan, L., and I. Zarishniak. "The Role of Elective Courses in Students' Professional Development: Foreign Experience." Comparative Professional Pedagogy, vol. 7, no. 2, 2017, pp. 20-26.

Nault, D. "Going Global: Rethinking Culture Teaching in ELT Contexts." Language, Culture and Curriculum, vol. 19, no. 3, 2006, pp. 314-328. 
Pugach, M. C., L. P. Blanton, and V. I. Correa. "A Historical Perspective on the Role of Collaboration in Teacher Education Reform: Making Good on the Promise of Teaching All Students." Teacher Education and Special Education, vol. 34, no. 3, 2011, pp. 183200.

Pym, A. "Where Translation Studies Lost the Plot: Relations with Language Teaching." Translation and Translanguaging in Multilingual Contexts, vol. 4, no. 2, 2017, pp. 164189.

Sinclair, C. "Initial and Changing Student Teacher Motivation and Commitment to Teaching.". Asia-Pacific Journal of Teacher Education, vol. 36, no. 2, 2008, pp. 79-104.

Swain, M., A. Kirkpatrick, and J. Cummins. How to Have a Guilt-free Life Using Cantonese in the English Class: A Handbook for the English Language Teacher in Hong Kong. Hong Kong: Research Centre into Language Acquisition and Education in Multilingual Societies, Hong Kong Institute of Education, 2011.

Tang, Y. F. “Teachers' Professional Identity, Educational Change and Neo-liberal Pressures on Education in Hong Kong.” Teacher Development, vol. 15, no. 3, 2011, pp. 363-380.

Tsagari, D., and G. Floros, eds. Translation in Language Teaching and Assessment. UK: Cambridge Scholars Publishing, 2013.

Tsai, Y., and A. Tsai. "Xue sheng xuan xiu fan yi ke cheng de xue xi dong ji tan tao 學生選修 翻譯課程的學曶動機探討.” Tamkang Studies of Foreign Languages and Literatures, vol. 20, 2012, pp. 57-72.

$\mathrm{Yu}, \mathrm{Li}$. "Communicative Language Teaching in China: Progress and Resistance". TESOL Quarterly, vol. 35, no. 1, 2001, pp. 194-197.

\footnotetext{
* Christy Fung-ming LIU - Dr. Liu holds a PhD in Translation and Intercultural Studies (2011) from the Universitat Rovira i Virgili, Spain. She is an Assistant Professor in the Department of Linguistics and Modern Language Studies at the Education University of Hong Kong. Her research interests focus on language teaching, language and translation, translation pedagogy and translation practices. Department of Linguistics and Modern Language Studies, The Education University of Hong Kong, Hong Kong. Tai Po, Hong Kong.

Academic website: https://repository.eduhk.hk/en/persons/fung-ming-christy-liu

ORCID: https://orcid.org/0000-0002-3090-0339

Email: liufm@eduhk.hk
} 